\title{
IMPLEMENTASI KETENTUAN PENDAFATARAN MEREK BERKAITAN DENGAN PENGGUNAAN KATA PADA PERUSAHAAN COFFEE SHOP DI KOTA DENPASAR*
}

\author{
Oleh: \\ Dika Samiaji Gustoro** \\ Ida Ayu Sukihana*** \\ Program Kekhususan Hukum Bisnis, \\ Fakultas Hukum, \\ Universitas Udayana
}

\begin{abstract}
ABSTRAK
Merek merupakan ruang lingkup dari pada Hak Kekayaan Intelektual merupakan suatu hak kebendaan yang sah dan diakui oleh hukum atas benda tidak berwujud berupa kreasi intelektual, yang dapat berupa hak merek seperti halnya hak kebendaan lainnya Hak Kekayaan Intelektual dapat beralih atau dialihkan dan dapat dipertahankan kepemilikannya oleh siapapun. Perlindungan hukum terhadap pemilik merek Indonesia merupakan suatu kewajiban apabila merek tersebut didaftarkan dan ini merupakan perlindungan yang bersifat preventif. Dengan hukum merek yang masih belum banyak masyarakat mengetahui bagaimana sistem perlindungan berkaitan dengan merek pada sebuah nama usaha agar salah satukarya intelektual mereka mendapatkan perlindungan hukum. Metode yang digunakan dalam penelitan ini adalah metode penelitian yuridis empiris, serta jenis pendekatan yang digunakan dalam penelitian ini yaitu pendekatan fakta pendekatan perundang-undangan. Maka tidak ada cara lain upaya hukum yang dapat dilakukan dengan cara mendaftarkan merek tersebut karena lebih memberikan jaminan perlindungan hukum dengan cara mendaftarkan merek pada nama perusahaannya.
\end{abstract}

Kata Kunci: Kekayaan Intelektual, Merek, Warung Kopi.

\footnotetext{
* Makalah ilmiah ini disarankan dan dikembangkan lebih lanjut dari skripsi yang ditulis oleh Penulis atas bimbingan Pembimbing Skripsi II Ida Ayu Sukihana.

** Dika Samiaji Gustoro adalah Mahasiswa Fakultas Hukum Universitas

Udayana. Korespondensi :dika_ajiht2@yahoo.com

*** Ida Ayu Sukihana adalah Dosen Fakultas Hukum Universitas Udayana.
} 


\begin{abstract}
Trademark is the scope of Intellectual Property Rights is a material right that is legal and recognized by law for intangible objects in the form of intellectual creations, which can be brand rights such as other material rights Intellectual Property Rights can be transferred or transferred and can be retained by anyone. Legal protection for the owner of the Indonesian brand is an obligation if the mark is registered and this is preventive protection. With brand law, there are still not many people who know how the protection system relates to the brand in a business name so that one of their intellectual works gets legal protection. The method used in this research is the empirical juridical research method, and the type of approach used in this study is the factual approach to the legal approach. So there is no other way of legal remedies that can be done by registering the trademark because it provides a guarantee of legal protection by registering the brand in the name of the company.
\end{abstract}

Keywords: Intellectual Property, Trademark, Coffee Shop.

\title{
I. PENDAHULUAN
}

\section{$1.1 \quad$ Latar Belakang}

Hak Kekayaan Intelektual (Intellectual Property Rights) digolongkan sebagai hak milik individual, yaitu hak kebendaan yang tidak berwujud (intangible rights). Berhubungan dengan HKI, istilah yang digunakan di Indonesia saat ini adalah "Kekayaan Intelektual (KI)". Di Indonesia singkatan HKI tidak lagi dipergunakan, namun lebih mengarah pada "KI" karena mengikuti yang mayoritas diterapkan di Negara-negara lain. ${ }^{1}$

Merek merupakan ruang lingkup dari pada Hak Kekayaan Intelektual, merupakan suatu hak kebendaan yang sah dan diakui oleh hukum atas benda tidak berwujud berupa kreasi intelektual yang dapat berupa hak merek seperti halnya hak kebendaan

${ }^{1}$ Ni Ketut Supasti Dharmawan et.al., 2016, Hak Kekayaan Intelektual (HKI), Deepublish (CV. Budi Utama) Yogyakarta, h.13. 
lainnya, Hak Kekayaan Intelektual dapat beralih atau dialihkan dan dapat dipertahankan kepemilikannya oleh siapa pun. ${ }^{2}$

Dalam konteks hukum merek sebuah kata pada nama tempat usaha dapat dijadikan sebagai merek dagang yang bertujuan untuk membedakan sebuah tempat usaha dengan tempat usaha lainnya yang menjual produk sejenis. Maka dari itu penting adanya perlindungan hukum bagi pemilik merek yang sah untuk memberikan hak yang sifatnya khusus (exclusive) bagi pemilik merek (exclusive right) agar pihak lain tidak dapat menggunakan tanda yang sama atau mirip dengan yang dimilikinya baik untuk barang atau jasa yang sama atau hampir sama. "Hak khusus tersebut cenderung bersifat monopoli, artinya hanya pemilik merek yang dapat menggunakannya". ${ }^{3}$

Merek termasuk salah satu kategori yang diatur oleh Kekayaan Intelektual didalam Undang - Undang No.20 Tahun 2016 tentang Merek dan Indikasi Geografis. Merek memegang kewajiban penting dalam sebuah usaha karena merupakan petunjuk bagi konsumen untuk membedakannya dengan usaha yang sejenis dan yang menjadi pesaingnya. Merek juga berfungsi untuk menjaga loyalitas konsumen terhadap sebuah produk, dapat membedakan sebuah produk atau usaha dari sekian banyak produk atau usaha yang serupa bila tidak ditandai dengan merek.

Ada beberapa Coffee Shop yang berada di Kota Denpasar terdiri dari 3 tempat, yaitu Hari Ini Coffee, Cheers Coffee dan juga Bron Coffee adalah pemilik pertama atas nama tempat usaha

2 Munir Fuady, 2008, Pengantar Hukum Bisnis Menata Bisnis Modern di Era Global, PT. Citra Aditya Bakti, Bandung, h.203.

${ }^{3}$ Kadek Yoni Vemberia Wijaya, I Gusti Ngurah Wairocana, 2018, Upaya Perlindungan Hukum Terhadap Pelanggaran Hak Merek, Kertha Semaya : Journal Ilmu Hukum, [S.1.], ISSN 2303-0569, Vol. 06, No. 03, Mei 2018, h.2. 
Coffee Shop yang berada di Kota Denpasar, dimana pemillik merek tidak mendaftarkan mereknya sehingga pemilik usaha resah akan dirugikan atau dipergunakan mereknya oleh pihak lain tanpa izin dengan suatu itikad buruk. Dengan adanya sistem pendaftaran merek konstitutif (First to File) maka yang dilindungi adalah pendaftaran pertama, tetapi pada kenyataannya pemilik usaha tidak mendaftarkan mereknya karena ketidaktahuan dan minimnya pengetahuan mereka akan sistem pendaftaran yang menjadikan syarat mutlak bagi timbulnya hak, sehingga pemilik usaha yang tidak mendaftarkan mereknya sering dirugikan dan dipergunakan oleh pihak lain tanpa izin.

Dengan hukum merek yang masih belum banyak masyarakat mengetahui bagaimana sistem perlindungan berkaitan dengan merek pada sebuah nama usaha agar salah satu karya intelektual mereka mendapatkan perlindungan hukum.

\subsection{Rumusan Masalah}

Berdasarkan dari masalah diatas, maka dapat diangkat beberapa persoalan yang timbul diantaranya:

1. Bagaimana implementasi pendaftaran merek bagi perusahaan Coffee Shop di Kota Denpasar?

2. Bagaimana akibat hukum bagi perusahaan Coffee Shop yang tidak mendaftarkan mereknya?

\subsection{Tujuan Penelitian}

Adapun tujuan penelitian ini guna menentukan hasil yang diperoleh dari suatu penelitian. Tujuan penelitian ini adalah untuk mengetahui pelaksanaan pendaftaran merek bagi perusahaan Coffee Shop di Kota Denpasar serta untuk mengetahui akibat hukum yang terjadi bagi perusahan Coffee Shop yang tidak mendaftarkan mereknya. 


\section{ISI MAKALAH}

\subsection{Metode Penelitian}

Adapun inti pada suatu metodelogi dari setiap penelitian hukum adalah menguraikan tentang tata cara bagaimana suatu penelitian hukum tersebut wajib dilakukan. 4 Penelitian ini menggunakan jenis penelitian hukum empiris. Dalam penelitian hukum empiris, adanya hukum yang di konsepkan sebagai suatu gejala empiris yang bisa diamati dalam kehidupan nyata. Yakni sebagai penelitian hukum yang mengambil datanya dilakukan secara langsung kepada informan sebagai data utama dalam penelitian. Jenis pendekatan yang ada didalam penelitian ini adalah pendekatan statute approach (perundang-undangan) dan pendekatan the fact approach (fakta).

\subsection{Hasil dan Pembahasan}

\subsubsection{Pelaksanaan Pendaftaran Merek Bagi Pengguna Kata Usaha Coffee Shop di Kota Denpasar}

Perlindungan hukum atas merek di Indonesia saat ini diatur berdasarkan Undang - Undang No.20 Tahun 2016 tentang Merek dan Indikasi Geografis yang menjadikan hasil dari pembaharuan undang - undang lama. Tentang perlindungan atas merek merupakan tahapan dari perlindungan hukum terhadap persaingan curang yang perbuatannya melawan hukum dibidang perdagangan. Merek dibedakan atas 3 jenis, yaitu : ${ }^{5}$

1. Merek Dagang

Merek dagang adalah merek yang digunakan pada barang yang diperdagangkan oleh seseorang atau

\footnotetext{
${ }^{4}$ Bambang Waluyo, 2008, Penelitian Hukum Dalam Praktek, Sinar Grafika, Jakarta, h.17.

${ }^{5}$ Nyoman Supariyani, 2016, Perlindungan Hak Kekayaan Intelektual Terhadap Tas Bermerek Yang Diimport Ke Indonesia, Jurnal Magister Hukum Udayana Jurnal, ISSN 2502-3101, Vol. 5, No. 2 : 281 - 291, Juli 2016, h.285.
} 
beberapa orang secara bersama-sama atau badan hukum untuk membedakan dengan barang-barang sejenis lainnya.

2. Merek jasa

Adalah merek yang digunakan pada jasa yang diperdagangkan oleh seseorang atau beberapa orang secara bersama-sama atau badan hukum untuk membedakan dengan jasa-jasa sejenis lainnya.

3. Merek kolektif

Adalah merek yang digunakan pada barang dan/atau jasa dengan karakteristik yang sama yang dengan dperdagangkan oleh beberapa orang atau badan hukum secara bersama-sama untuk membedakan dengan barang dan/atau jasa sejenis lainnya.

Di Indonesia menganut sistem pendaftaran merek dengan sistem First to File Principle (konstitutif), dengan sistem konstitutif maka yang dilindungi adalah pendaftaran pertama. ${ }^{6}$ Menjadikan pendaftaran merupakan suatu kewajiban agar mendapatkan hak merek, tanpa pendaftaran Negara tidak akan memberikan hak atas merek kepada pemilik merek. Hal ini dapat diartikan tanpa seseorang tidak mendaftarkan merek maka tidak akan mendapatkan perlindungan.

Dalam perlindungan hukum mengenai merek berdasarkan ketentuan pasal 2 ayat (3) merek yang dilindungi terdiri atas tanda berupa gambar, logo, nama, kata, huruf, angka, susunan warna, dalam bentuk 2 (dua) dimensi dan/atau 3 (tiga) dimensi, suara, hologram, atau kombinasi dari 2 (dua) atau lebih unsur tersebut untuk membedakan barang atau jasa yang diproduksi oleh orang

6 Rika Ratna Permata, 2016, Perlindungan Hukum Merek Tidak Terdaftar di Indonesia, Jurnal Opinio Juris, Vol. 19 Januari - April 2016. 
atau badan hukum dalam kegiatan perdagangan barang atau jasa. $^{7}$

Sebagaimana telah di jelaskan sebelumnya bahwa merek baru mendapatkan perlindungan hukum HKI jika merek tersebut telah didaftarkannya di Dirjen HKI. Para pemilik merek wajib memenuhi persyaratan mulai dari administrasi dan subtansi untuk mendaftarkan mereknya. Adapun ketentuan tata cara permohonan pendaftaran berdasarkan pasal 4 sampai dengan pasal 8 Undang - Undang No.20 Tahun 2016 tentang Merek. Pasal 4 ayat (1) menjelaskan bahwa permohonan pendaftaran merek diajukan oleh Pemohon atau Kuasanya kepada Menteri secara elektronik atau non-elektronik dalam bahasa Indonesia. Di jelaskan pada pasal 4 ayat (2) denga permohonan sebagaimana dimaksud pada ayat (1) harus mencantumkan:

a. Tanggal, bulan, dan tahun permohonan;

b. Nama lengkap, kewarganegaraan, dan alamat pemohon;

c. Nama lenkap dan alamat Kuasa jika Pemohonan diajukan melalui Kuasa;

d. Warna jika merek yang dimohonkan pendaftarannya menggunakan unsur warna;

e. Nama Negara dan tanggal permintaan merek yang pertama kali dalam hal permohonan dengan hak prioritas

f. Kelas barang atau kelas jasa serta uraian jenis barang dan/atau jenis jasa.

Setelah memenuhi persyaratan administasi, tahapan selanjutnya pemeriksaan substantif. Jika dalam pemeriksaan substantive ternyata merek tersebut lolos untuk didaftarkan permohonan dapat disetujui untuk didaftar, dari persetujuan

7 Tim Lindsey, et.al., 2013, Hak Kekayaan Intelektual, PT. Alumni, Bandung, h.33. 
Direktur Jenderal Hak Kekayaan Intelektual permohonan tersebut akan diumumkan dalam Berita Resmi Merek. ${ }^{8}$ Dalam pendaftaran merek sangat penting untuk mengemukakan mengenai kelas dan jenis barang atau jasa yang dimohonkan pendaftarannya. ${ }^{9}$

Dalam pelaksanaannya ada beberapa coffee shop di Kota Denpasar seperti Cheers Coffee, Bron Coffee, dan Hari Ini Coffee berdasarkan hasil dari wawancara menjelaskan bahwa pemilik usaha sendiri belum pernah mendaftarkan mereknya di Direktorat Jenderal Kekayaan Intelektual sebagai sebuah merek dagang.

Berikut ini dari beberapa faktor - faktor yang mempengaruhi bagi pengusaha coffee shop yang berada di Kota Denpasar tidak mendaftarkan mereknya, yaitu:

1. Faktor Pemahaman

Dari hasil wawancara dengan Innayat Anhar (Owner/pemilik) Hari Ini Coffee yang berada di Kota Denpasar berlokasi di Jalan Pulau Tarakan No.17 Denpasar Barat menjelaskan terjadinya faktor penyebab tidak didaftarkan merek pada usaha coffee shop miliknya karena ketidaktahuan kata istilah coffee shop yang digunakan adalah sebuah merek, dan kurangnya pemahaman dari pemilik usaha tentang perlindungan hukum mengenai merek.

2. Proses Pendaftaran

Peranan merek menjadi sangat penting, merek pada hakikatnya dipakai oleh pemilik merek untuk melindungi produk -produk yang dihasilkannya.

8 Gatot Supramono, 2008, Menyelesaikan Sengketa Merek Menurut Hukum Indonesia, PT. Rineka Cipta, Jakarta, h.15.

${ }^{9}$ Ni Ketut Supasti Dharmawan, et.al., op.cit, h.72. 
Berdasarkan hasil wawancara dengan Egayana Putra (Owner/pemilik) Bron Coffee yang berada di Jalan Hayam Wuruk No.136 salah satu pemilik usaha coffee shop yang juga berada di Kota Denpasar, menjelaskan ketidaktahuannya dari pemilik usaha tentang prosedur pendaftaran masih dianggap cukup sulit serta biaya pendaftaran yang masih dianggap cukup mahal.

3. Kurang Sosialisasi

Berkaitan dengan merek kurangnya sosialisasi dari pemerintah dan para pihak dari instansi terkait dengan merek terhadap penggunaan nama pada perusahaan coffee shop bahwa kata istilah yang mereka gunakan pada usahanya adalah sebuah merek.

\subsubsection{Akibat Hukum Bagi Perusahaan Coffee Shop yang Tidak Mendaftarkan Mereknya}

Dengan sistem konstitutif (First to File) maka pendaftaran pertama yang akan dilindungi, akan tetapi pada kenyataannya pemilik merek tidak mendaftarkan mereknya karena ketidaktahuan mereka akan sistem pendaftaran yang menjadikan syarat mutlak bagi timbulnya hak, sehingga pemilik merek yang tidak mendaftarkan mereknya sering dirugikan dan dipergunakan oleh pihak lain tanpa izin.

Secara umum pendaftaran merek berfungsi menjadi alat bukti kepemilikan atas sebuah kata pada nama perusahan coffee shop. Selain itu juga berfungsi sebagai dasar penolakan terhadap merek yang sama secara keseluruhan atau sama pada pokoknya yang dimohonkan pendaftarannya serta menjadi dasar untuk mencegah orang lain untuk pemakaian merek yang sama secara 
keseluruhan atau pada pokoknya dalam peredaran barang atau jasa. ${ }^{10}$

Akibat hukum tidak didaftarkannya sebuah merek adalah tidak memperoleh perlindungan hukum dari Negara dan tidak akan mendapatkan hak eksklusif. Apabila merek tersebut tidak didaftarkan maka artinya siapapun berhak atas merek tersebut dan tidak merupakan suatu pelanggaran. Bagi merek yang dilisensikan tetapi belum didaftarkan hak pengalihannya tidak ada perlindungan hukum dari Negara berlandaskan Pasal 42 ayat (5) Undang - Undang No.20 Tahun 2016 tentang Merek menjelaskan bahwa perjanjian lisensi yang tidak dicatatkan tidak berakibat hukum pada pihak ketiga.

Berdasarkan wawancara dengan Bapak I Nyoman Mudana, SH., MH wakil ketua sentra HKI Universitas Udayana menjelaskan bahwa, akibat hukum dari lisensi tidak didaftarkannya merek tersebut menjadi batal demi hukum, karena tidak ada obyek sebab perjanjian dianggap tidak ada dan status pada merek tersebut menjadi public domain (menjadi milik umum).

Berdasarkan wawancara dengan Bapak I Made Dedy Priyanto, SH., M.Kn sekretaris senta HKI Universitas Udayana menjelaskan bahwa, tidak ada pendaftaran maka merek tidak diakui sehingga tidak boleh melakukan perjanjian lisensi dikarenakan tidak mendapatkannya hak eksklusif dari hak pengguna terkait merek. Dalam pasal 1320 KUHPerdata mengenai perjanjian berasakan itikad baik dan kepercayaan merupakan perjanjian umum biasa, namun tidak untuk perjanjian lisensi. Hal tersebut melanggar pasal 1320 KUHPerdata Nomor 3 dan 4 dalam

10 Adfiyanti Fadjar, 2016, Penggunaan Nama yang Sama Pada Usaha Sejenis Menurut Perspektif Hukum Merek, Jurnal Lex Librum, Vol. II, No.2 Palu, Juni 2016. 
hal obyektif tertentu tidak memenuhi syarat karena belum memenuhi kapsitas dalam suatu perjanjian, kapasitas dalam arti orang yang bisa bertindak hukum.

\section{PENUTUP}

\subsection{Kesimpulan}

1. Pelaksanaan pendaftaran merek bagi perusahaan coffee shop di Kota Denpasar belum maksimal, karena pemilik coffee shop kurangnya pemahaman berkaitan dengan merek atas ketidaktahuan merek mengenai kata istilah coffee shopnya yang digunakan adalah sebuah merek dan kurangnya sosialisasi berkaitan dengan merek dari para pihak instansi yang terkait dengan merek.

2. Akibat hukum bagi perusahaan coffee shop yang tidak mendaftarkan mereknya maka merek tersebut tidak akan mendapatkan perlindungan hukum dari Negara, tidak ada pendaftaran maka merek tersebut tidak diakui, tidak mendapatkannya hak eksklusif dai hak pengguna terkait merek, dan status pada merek tersebut menjadi public domain (menjadi milik umum).

\subsection{Saran}

1. Pada pelaksanaan ketentuan pendaftaran merek bagi pengguna kata usaha coffee shop yang berada di Kota Denpasar terkait dengan perlindungan hukum pihak owner (pemilik) dapat segera mendaftarkan merek pada nama perusahaannya ke Dirjen HKI guna memperoleh perlindungan hukum dari Negara agar tidak menimbulkan dugaan akan adanya hak sebagai pengguna pertama oleh pihak lain dari merek tersebut. 
2. Perlunya sosialisasi yang dilakukan pemerintah dan para pihak dari instansi terkait merek kepada pemilik usaha coffee shop untuk memberikan pemahaman mengenai kata istilah yang digunakan adalah sebuah merek.

\section{DAFTAR PUSTAKA}

\section{Buku - buku}

Bambang Waluyo, 2008, Penelitian Hukum Dalam Praktek, Sinar Grafika, Jakarta.

Gatot Supramono, 2008, Menyelesaikan Sengketa Merek Menurut Hukum Indonesia, PT. Rineka Cipta, Jakarta.

Munir Fuady, 2008, Pengantar Hukum Bisnis Menata Bisnis Modern di Era Global, PT. Citra Aditya Bakti, Bandung.

Supasti Dharmawan Ni Ketut et.al., 2016, Hak Kekayaan Intelektual (HKI), Deepublish (CV. Budi Utama) Yogyakarta.

Tim Lindsey, et.al., 2013, Hak Kekayaan Intelektual, PT. Alumni, Bandung.

\section{Peraturan Perundang - undangan}

Indonesia, Undang-Undang Republik Indonesia Nomor 20 Tahun 2016 tentang Merek dan Indikasi Geografis.

Indonesia, Undang-Undang Republik Indonesia Nomor 7 Tahun 1994 tentang Pengesahan Agreement Establishing The World Trade Oranization (Persetujuan Pembentukan Organisasi Perdagangan Dunia).

Indonesia, Peraturan Menteri Hukum dan HAM Republik Indonesia Nomor 67 Tahun 2016 tentang Pendaftaran Merek.

Kitab Undang-Undang Hukum Perdata, Burgelijk Wetboek, 2008, diterjemahkan oleh Subekti, R. dan Tjitrosudibio, Pradnya Paramita, Jakarta.

\section{Artikel Jurnal}


Adfiyanti Fadjar, 2016, Penggunaan Nama yang Sama Pada Usaha Sejenis Menurut Perspektif Hukum Merek, Jurnal Lex Librum, Vol. II, No.2 Palu, Juni 2016.

Rika Ratna Permata, 2016, Perlindungan Hukum Merek Tidak Terdaftar di Indonesia, Jurnal Opinio Juris, Vol. 19 Januari - April 2016.

Supariyani Nyoman, 2016, Perlindungan Hak Kekayaan Intelektual Terhadap Tas Bermerek Yang Diimport Ke Indonesia, Jurnal Magister Hukum Udayana Jurnal, ISSN 2502-3101, Vol. 5, No. $2: 281-291$, Juli 2016.

Yoni Vemberia Wijaya Kadek, Wairocana I Gusti Ngurah , 2018, Upaya Perlindungan Hukum Terhadap Pelanggaran Hak Merek, Kertha Semaya : Journal Ilmu Hukum, [S.1.], p. 1-6, may 2018. ISSN 2303-0569, Vol. 06, No. 03, Mei 2018. 